Jurnal Administro Vol 2, No 1, pp 17-22,Tahun

\title{
Analisis Kompetensi Manajerial Pejabat Struktural Di Fakultas Ilmu Sosial Universitas Negeri Manado
}

\author{
Jeane Elisabeth Langkai a, ${ }^{*}$ \\ a Universitas Negeri Manado, Ilmu Administrasi Negara, Tondano Indonesia \\ 1 jeanelangkai@unima.ac.id*
}

IN F O ART IKEL

Diterima 00 April 00

Disetujui 00 Oktober 00

Key word:

Managerial Competence,

Structural Officials

\section{A B S T R A C T}

This study aims to analyze the managerial competence of the structural officers of the Faculty of Social Sciences UNIMA through the availability of: a). structural official profile data, both software and hardware, b). describe and analyze structural official profiles. The importance of research priority is that the managerial competence of structural officials is regulated through PP No.11 of 2017 which is called the Civil Service Management Policy which defines three competencies, namely: Technical Competence, Managerial Competence and SocioCultural Competence where these three competencies must be owned by structural officials as an obligation. in serving the public [1]. The absence of implementing the competence of structural officials will have an impact on the fatness of the work results and continue to delay the administrative process which disrupts the smooth process and the target achievement of graduates produced at FIS UNIMA.

The activities in this research are: 1. Conducting field surveys on the implementation of main tasks and functions carried out by structural officials, 2. Conducting FGDs with leaders of faculties, study programs, lecturers and students 3. conducting profile descriptions, 4. compiling reports, 5. arranging article

The output of this research activity is: 1. Data on managerial competence analysis of structural officials, 2. Data for managerial training needs profile, 3. Profile description of structural officers, 4. Research reports, 5. Articles submitted in accredited national journ.

\section{INTISARI}

Penelitian ini bertujuan melakukan analisis tentang kompetens manajerial pejabat struktural Fakultas Ilmu Sosial UNIMA melalu tersedianya: a). data profil pejabat structural baik software maupu hardware, b). mendeskripsi dan menganalisis profil pejaba structural. Urgensi keutamaan penelitian adalah bahwa kompetens manajerial pejabat struktural diatur melalui PP No.11 Tahun 201' yang disebut dengan Kebijakan Manajemen Pegawai Negeri Sipi yang menetapkan tiga kompetensi yakni: Kompetensi Teknis Kompetensi Manajerial dan Kompetensi Sosial Kultural diman ketiga kompetensi tersebut harus dimiliki pejabat sruktural sebaga 
kewajiban dalam melayani public [1]. Belum dilaksanakany kompetensi pejabat sruktural akan berdampak pada lemaknya hasi kerja dan berlanjut pada tertundanya proses administrative yan: mengganggu kelancaran proses dan target caaian lulusan yan; dihasilkan pada FIS UNIMA. Kegiatan dalam penelitian ini adalah 1.melakukan survey lapangan tentang pelaksanaan tugas pokok da] fungsi yang terlaksanan oleh pejabat struktural, 2.Melakukan FGI dengan pimpinan fakultas, prodi, dosen dan mahasisw: 3.melakukan deskripsi profil , 4.menyusun laporan, 5. menyusus1 artikel Luaran dari kegiatan penelitian ini adalah: 1.Data analisi kompetensi manajerial pejabat structural, 2.Data profil kebutuha] pelatihan manajerial, 3. Deskripsi profil pejabat struktural, 4 .Laporan hasil penelitian, 5.Artikel yang tersubmit pada jurna nasional terakreditasi.

\section{Copyright (C) 2019 (Jeane Langkai). All Right Reserved}

\section{Pendahuluan}

Pengangkatan PNS dalam jabatan tertentu berdasarkan perbandingan objektif antara kompetensi, kualifikasi, dan persyaratan yang dibutuhkan oleh jabatan dengan menetapkan tiga kompetensi yakni: a). Kompetensi Teknis b). Kompetensi Manajerial, c). Kompetensi Sosial Kultural, (PP No.11 tahun 2017) dan Keputusan Kepala Badan Kepegawaian Negara Nomor 8 Tahun 2013) [2]. Fakultas Ilmu Sosial UNIMA terdapat 27 Pegawai dengan 5 pejabat structural yang terdiri dari Kepala Bagian Tatausaha, Kepala sub bagian Akademik, Kepala sub bagian Kemahasiswaan, Kepala sub bagian Pendidikan dan Kepala sub bagian Keuangan. Hasil observasi menunjukkan terdapat beberapa tugas pokok dan fungsi bidang kemahasiswaan, keuangan, pendidikan dan umum dan perlengkapan yang belum dikelola sebagaimana yang diharapkan oleh kebijakan tersebut. Selain itu terdapat kecenderungan tertundanya beberapa kegiatan akaemik, kemahasiswaan dan lambannnya pelayanan pada bagian akademik,kemahasiswaan, sarana prasarana penunjang kegiatan akademik.

\section{Metode Penelitian}

Penelitian menggunakan jenis penelitian survei. Subjek Penelitian, terdiri atas: 1). Peneliti, 2). Mahasiswa, 3).pimpinan, 4). Dosen. Instrumen penelitian melakukan analisis mengenai: kompetensi manajerial, (2) tujuan. Analisis Data, dianalisis secara deskriptif.

\section{Hasil dan Pembahasan}

Herkolanus, Syamsuni Arman, Sugito membahas tentang proses pelaksanaan pengangkatan PNS dalam Jabatan Struktural secara umum telah dilaksanakan sesuai dengan ketentuan yang berlaku [3]. Namun apabila memperhatikan kompetensi pejabat yang mendudukinya masih belum memenuhi persyaratan jabatan sebagaimana dikemukakan dalam analisis jabatan. Penilaian kinerja seperti kualitas pelayanan, responsivitas, responsibilitas dan akuntabilitas meskipun secara umum terdapat peningkatan kinerja namun belum sepenuhnya mampu memenuhi harapan layaknya seseorang untuk dipertimbangkan dalam jabatan. Belum terdapat prosedur standar dalam memberikan pelayanan dan kurang disiplinnya PNS masih merupakan bagian hambatan peningkatan kinerja. Hal lain yang juga perlu untuk mendapatkan perhatian adalah tingkat responsivitas dalam memerikan pelayanan kepada masyarakat pada umumnya. Masih terdapat faktor penghambat pengangkatan dalam jabatan struktural baik berasal dari dalam organisasi seperti program aplikasi komputer yang belum mampu untuk memberikan informasi yang akurat data riwayat jabatan dan daftar urut kepangkatan. Sedangkan faktor eksternal adalah masih terdapat intervensi terhadap pengangkatan dalam jabatan struktural melalui pertimbangan politis (spoil system).
A. Profil Tenaga Dosen dan tenaga Kependidikan 


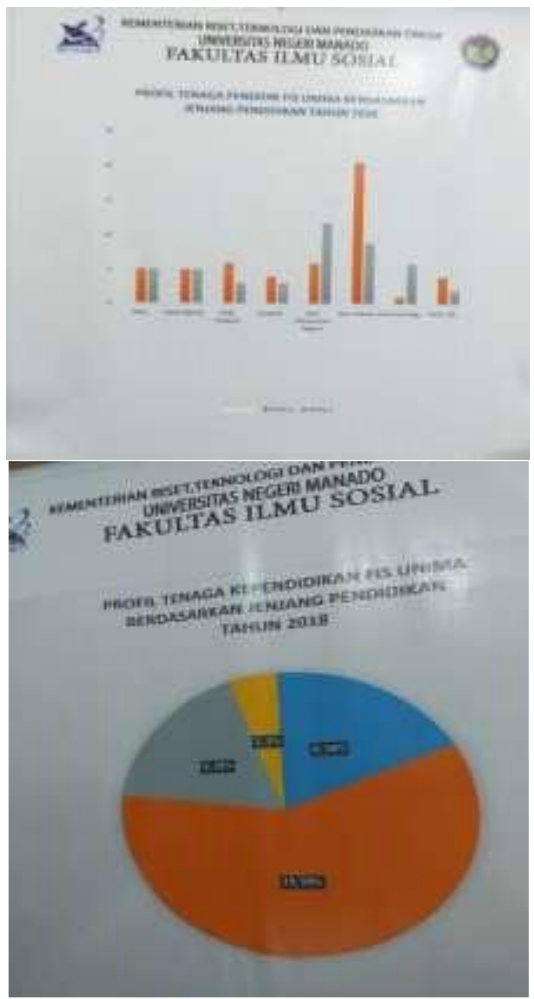

\section{B. Subbagian Umum dan Perlengkapan}

Kepala Subbagian Umum dan Perlengkapan adalah Ribka Tangalayuk.SPd. Adapun tugas pokok dan fungsi secara umum dari bidang subbagian umum dan perlengkapan adalah diantaranya: a). Menyusun rencana, membagi tugas, memberi petunjuk dan menilai pokok pelaksanaan kegiatan bawahan di lingkungan sub bagian umum dan perlengkapan serta melaksanakan urusan persuratan, kerumahtanggaaan dan perlengkapan fakultas, berdasarkan ketentuan yang berlaku demi kelancaran pelaksanaan lugas, b). Menegur bawahan yang lalai melaksanakan tugas, c).

Menentukan prioritas pekerjaan, d). Memberi nilai DP3 bawahan, e). Memaraf surat dan dokumen dinas sesuai ketentuan, e). Menolak hasil kerja bawahan yang tidak relevan, f). Meminta petunjuk atasan, g). Menyetujui cuti/izm bawahan. Sedangkan tanggungjawabnya adalah: a). Pendayagunaan ATK dan APK, b). Kerahasiaan surat, dokumen, data dan informasi, c). Kebenaran laporan pelaksanaan tugas. Selanjutnya: a). Menyusun program kerja tahunan sub. Bagian dan mempersiapkan tugas penyusunan program kerja tahunan sub bagian, b). Melaksanakan urusan "surat-surat, pengetikan dan pengadaan ekspedisi, pengiriman dan kearsipan, d). Memelihara kebersihan, keindahan dan keamanan ruang kantor, halaman, ruang kuliah/lab serta fasilitas unvum lainnya, d). Melaksanakan urusan tamu pimpinan, upacara dan pertemuan resmi lainnya dan perjalanan dinas, e).Melaksanakan urusan administrasi hubungan masyarakat dan kerjasama dengan pihak lainnya, f ). Menyusun rencana pengadaan barang perlengkapan, g). Melakukan inventarisasi dan mempersiapkan penghapusan basa: perlengkapan, $\mathrm{h}$ ). Melakukan penyimpanan, pendistribusian dan perawatan barang-barang perlengkapan.

Kompetesi manajerial Kasubag umum dan perlengkapan menyangkut kemampuan melakukan perencanaan, mengorganisasikan apa yang direncanakan, mengaktualisasikan apa yang direncanakan, melakukan kontrol berdasarkan tugas pokok dan fungsi sebagaimana ditetapkan dalam kebijakan atau sebagaimana yang terurai sebelummya. Hasil wawancara dengan pegawai FIS (ES) tanggal 7 Oktober secaa khusus dalam kemampuan merencanakan kebutuhan pengadaan barang untuk kegiatan kebersihan ruangan kualiah, toilet, kebutuhan penyelenggaraan perkuliahan seperti Laptop, LCD kertas dan lainnya, diperoleh informasi bahwa kegiatan tersebut dilakukan secara rutin berdasarkan analisis kebutuhan dan hal ini dibenarkan oleh Kepala

Tata Usaha. Tetapi dalam kegiatan penyelengaraan dan perngorganisasian, didapati bahwa wc di fakultas sangat tidak memenuhi sayarat berdasar jumlah mahasiswa dan jumlah dosen dan pegawai. Ketika dikonfirmasikan kepada kasubag umum perlengkapan, ternyata selalu ada perencanaan, tetapi perencanaan tersbut kdng hany rencna begitu saja dan tidk ada tindak lanjut dalam pengadaan kebutuhan. Sudah menjadi masalah "klise" dri tahun ketahun. Begitu juga dalam pengadaan papan tulis, LCD dan kebutuhan perkuliahan semua sudah direncanakan berdasarkan analisis kebutuhan, tetapi dalam realisasinya belum sesuai dengan kebutuhan pelaksanaaan pembelajaran setiap jurusan dan program studi. Permasalahannya bukan pada kompetensi pejabat struktural pada tingkat fakultas tetapi lebih pada realisasi pejabat tugas tambahan yang kadang elum dilakukan secara transparansi antara analisis kebutuhan dan realisasi berdasar rencana. Hampir setiap jam perkuliahan pada pukul 8.00 dosen pada setiap jurusan dan prodi berebut LCD bahkan ada dosen yang terpaksa tidak mengembalikan barang pinjamannya karena besoknya akan saling berebutan. Begitu juga meja dosen dalam perkuliahan sudah sangat tidak layak. Bahkan papan tulis dikelas terdapat papan tulis yang tidak layak pakai. Ketika dikonfrmasikan kepada Kasubag umum perlengkapan, semua itu sudah direncanaakan tetapi belum terealisasi dan itu dibenarkan oleh Kabag Tatausaha. Kondisi inimemperlemah motivasi dosen untuk meningkatkan kinerja dalam melaksanakan pemelajaran. 


\section{Sub bagian Kemahasiswaan.}

Kepala subbagian kemahasiswaan adalah Dra. Rahaimah Soleman. Adapaun tugas pokok dan fungsinya diantaranya adalah:

a).Menyusun program kerja tahunan sub bagian kemahasiswaan,

b).Menhimpun dan mengkaji peraturan perundangundangan dibidang kemahasiswaan,

c).Mengumpulkan, mengolah dan menganalisis kemahasiswaan,

d).Melakukan urusan pemberian izim'rekomendasi kemahasiswaan,

e).Mempersiapkan usul pemilihan Mahasiswa Berprestasi.

f).Mempersiapkan pelaksanaan kegiatan kemahasiswaan,

g).Melakukan administrasi kegiatan kemahasiswaan,

h).Melakukan pengurusan beasiswa, pembinaan karir dan kesejahteraan mahasiswa.

Dari hasil wanwancara dengan mahasiswa dari prodi administrasi Negara semester VII EK, UT, IM diperoleh infrmasi bahwa mereka kadang sulit mengetahui kapan seleksi penerimaan beasiswa bahkan mereka tidak membaca pengumuman ada papan pengumuman. Ketika dikonfirmasi kepada pegawai bagian kemahasiswaan dan kasubag kemahasiswaan, ternyata informasi tersebut disampaikan kepada pimpinan jurusan dan prodi dan yang menentukan siapa yang memperoleh beasiswa adalah pimpinan jurusan dan prodi walaupun mereka ditugasi melakukan urusan beasiswa. Selanjutnya dalam kegiatan ekstra kurikuler kemahasiswaan diakui bahwa kadang jarang terjdi komunikasi antara pembanu Dekan II dengan kasubag kemahasiswaan juga dngan mahasiswa dalam melakukan kegiatan ektra seperti lomba debat, kegiatan kerohanian dan lainnya. Pada umummnya kegiatan tersebut dilakukan langsung oleh pembntu dekan bidang kemahasiswaan. Dalam kegiatan kerohanian kemahasiswaan bagian kemahasiswaan ini jarang terlibat bahkan belum pernah mengetahui pembiayaan kegiatan tersebut. Kondisi tersebut ketika dikonfirmasi dengan mahasiswa yang terjun dalam kegiatan kerohanian, mereka mengakui bahwa kegiatan mereka tidak dibiayai oleh fakultas dan mereka pernah menyampaikan kepada pembantu dekan tida dan dikonfirmsikan kepada dekan, diperoleh informs bahwa untuk kegiatan tersebut tidak ada dana dari fakultas.

\section{Subbagian Pendidikan}

Kepala subbagian pendidikan adalah Dra. Meyti K Malingkas. Adapun tugas pokok dan fungsinya adalah:
a).Menyusun rencana dan program kerja,

b) Mengelola sumber daya manusia,

c).Menghimpun informasi di bidang kurikulum, silabus, prestasi belajar mahasiswa, terkait kegiatan pendidikan dan pengajaran sebagai bahan pertimbangan penyusunan kebijaksanaan, d). Mengatur penggunaan sarana akademik untuk kelancaran kegiatan proses belajar megajar,

e).Mengoordinasi pelaksanaan urusan administrasi akademik berdasarkan data dan informasi yang diperlukan mulai dari mahasiswa baru masuk hingga mahasiswa lulus,

f).Membuat surat keputusan terkait kegiatan pendidikan dan pengajaran

g).Mengoordinasikan Pelaksanaan Perkuliahan

h). Mengoordinasikan Pelaksanaan Penyelenggaraan Ujian Akhir Semester dan Midsemester.

Terdapat kegiatan tumpang tindih antara tugas pokok dan fungsi dari kasubag bidag pendidikan dan subbagian umum perlengkapan khususnya dalam tersedianya fasilitas belajar mengajar dikelas dan pada saan ujian seminar proposal, ujian hasil dan komprehensisf, dimana belum tersediny laptop dan LCD.

Sebaiknya dalam kegiatan yng berkaitan dengan kompetensi manajerial pejabat structural pada fakultas selalu tercipta kerja sama antara subbagian umum perlengkapan, subbagian pendidikan, kepala bagian tatausaha, pembantu dekan I,II dan III agar terjadi snergitas antara semuanya demi kelancaran tugas pokok fungsi masing-masing untuk menujang kinerja dosen dn mhsiswa sert meningkatkan hasil kerja fakultas pada umummnya. Memang terdapat data bahwa di fakults ilmu social belum terdapat surat keputusan dekan tentang tugas pokok dan fungsi masing-masing pejabat structural, maka dampaknya adalah antara kompetensi manajerial dalam hal Planning, organizing, actuating, controlling $n$ budgeting tidk berjlan sebagaimana mestinya. Padahal fakultas ilmu social memiliki mhasiswa yang banyak dega jumlah penyetoran UKT dan Partisipasi yang cukup tinggi.

\section{E. Kepala Bagian TataUsaha}

Kepala Bagian Tata Usaha FIS UNIMA adalah Djolly V Waroka.SPd yang membidang sub bagian kemahasisaan, sub bidang kepegawaian dan keuangan, sub bagian umum dan perlengkapan dan sub bagian pendidikan. Adapun yang merupakan tugas kepala bagian tata usata diantarannya adalah:

a). memimpin tugas-tugas administrasi antaralain:Administrasi akademik, Administrasi keuangan dan kepegawaian, administrasi umum dan 
perlengkapan dan administrasi kemahasiswaan dan alumni,

b). Menyusun rencana dan program kerja tahunan,

c).Melaksanakan administrasi pendidikan, penelitian untuk mengembangkan ilmu pengetahuan, tekhnologi dan kesenian,

d).Melaksanakan administrasi pengabdian kepada masyarakat pembina aktivitas akademika dan urusan tata usaha fakultas,

e).Menilai prestasi keja bawahan dilingkungan bagian tata,

f).Menghimpun, menelaah dan menyebarluaskan peraturan perundang-undangan yang berhubungan dengan fakultas,

g).Memelihara kebersihan, keindahan dan keamanan ruang kantor, ruang kuliah dan fasilitas umum lainnya,

h).Mengurus rapat dinas, upacara resmi dan pertemuan lainnya,

i).Melaksanakan urusan perlengkapan yang meliputi perencanaan pengadaan, penyimpanan, pendistribusian, perawatan inventarisasi dan usul penghapusan barang perlengkapan,

j).Mempersiapkan/melaksanakan urusan kepegawaian yang meliputi penyusunan formasi, pengadaan, usul mutasi, pembinaan dan kesehjateraan pegawai,

k). Melaksanakan administrasi hubungan masyarakat dan kerjasama dengan pihak lainnya,

i). Menyelenggarakan dan mengkoordinasi kegiatan administrasi umum yang meliputi bidang ketata usahaan, akademik, kepegawaian, dan perlengkapan di lingkungan fakultas.


menglakukan kontrol berdasarkan tugas pokok dan fungsi sebagaimana ditetapkan dalam kebijakan. Hasil wawancara dengan pegawai FIS (MK) tanggal 7 oktober dan informasi tersebut dikonfirmasi pada kepala sub bagian kemahasiswaan MM, kepada kepala bagian kepegawaian dan keuangan MS, kepala bagian umum dan perlengkapan RT dan kepala bagian kemahasiswaan RS secara keseluruhan menyetujui tugas pokok dan fungsi kepala bagian tatausaha sudah diusahakan dilaksanakan namun kadang kala terjadi tumpang tindih antara tugas pokok dan fungsi pembantu dekan bidng 1, bidang 2, bidang 3 dan 4 . Ketika dicari informasi selanjutnya maka didapati bahwa di FIS belum ditetapkan secara rinci tugas pokok dan fungi pejabat struktural dalam bentuk Surat keputusan Dekan, dan hal ini berdampak pada ketidak jelaskan tugas pokok dan fungsi kepala bagian tatausaha. Kompetensi manajerial kepala bagian Tata usaha banyak kali terhambat untuk difungsikan karena sangat bergantung dari perintah pejabat tugas tambahan yang memang belum ditetapkan secara tegas tentang tugas pokok dan fungsi masing masing pejabat tugas tambahan. Dalam prakteknya pelaksanaannya sangat bergantung pada perintah atasan pejabat tugas tambahan. Akibatnya kepala bagian tata usana tidak dapat melaksanakan kompetensi manajerial yang dimulai dari perencanaan, pengorganisasian, penggerakan dan pengontrolan.Fungsi-fungsi manajemen sebagai kabag TU jarang diimplementasikan karena belum terdapat ketegasan akan tugas pokok dan fungsi.

Manajemen kepegawaian merupakan fungsi dasar pada serangkaian upaya-upaya untuk meningkatkan efisiensi, efektifitas, dan derajat profesionalisme yang meliputi perencanaan, pengadaan, pengembangan kualitas, penempatan, promosi, dan penggajian, kesejahteraan, dan pemberhentian Pegawai Negeri Sipil. Flippo mengemukakan perencanaan, pengorganisasian, pengarahan, dan pengendalian dari pengadaan, pengembangan, kompensasi, pengintegrasian, pemeliharaan, dan pemberhentian karyawan/pegawai, dengan maksud terwujudnya tujuan organisasi, individu, karyawan/pegawai, dan masyarakat) [4]. Pegawai negeri sipil merupakan dalam tugas pokok dan fungsinya berdampak terhadap efektivitas organisasi. Dalam arti SDM dalam hal ini Pejabat structural pada Fakultas Ilmu Sosial merupakan faktor strategis dalam kegiatan organisasi. Pejabat sruktural pada Fakultas Ilmu Sosial wajib memiliki kompetensi. Sebagaimana yang ditetapkan dalam PP No. 11 Tahun 2017. Stephen J. Kenezevich menyebutkan bahwa kompetensi merupakan kemampuan mencapai tujuan organisasi [5], sedangkan Mitrani A, mengemukakan kompetensi sebagai sifat dasar yang berkaitan dengan pelaksanaan suatu pekerjaan [6], Lyle M. Spencer dan Signe M. Spencer, kompetensi sebagai karakteristik yang mendasari seseorang dan berkaitan dengan efektifitas kinerja individu [7]. Jabatan struktural merupakan kedudukan yang menunjukan tugas, tanggung jawab, wewenang, dan hak seorang Pegawai Negeri Sipil dalam rangka menyelenggarakan tugas pokok dan fungsinya memimpin suatu satuan organisasi negara. Kedudukan jabatan struktural memiliki tingkatan-tingkatan atau bertingkat-tingkat mulai dari yang terendah (eselon V) hingga tingkat yang tertinggi (eselon I/a).

Manajemen Pegawai Negeri Sipil menetapkan tiga kompetensi yakni: Kompetensi Teknis yaitu pengetahuan, keterampilan, dan sikap/perilaku yang dapat diamati, diukur, dan dikembangkan yang spesifik berkaitan dengan bidang teknis Jabatan. Kompetensi Teknis diukur dari tingkat dan spesialisasi pendidikan, pelatihan teknis fungsional, dan pengalaman bekerja secara teknis. Kompetensi 
Manajerial yaitu pengetahuan, keterampilan, dan sikap/perilaku yang dapat diamati, diukur, dikembangkan untuk memimpin dan/atau mengelola unit organisasi. Kompetensi Manajerial diukur dari tingkat pendidikan, pelatihan struktural atau manajemen, dan pengalaman kepemimpinan. Kompetensi Sosial Kultural yaitu pengetahuan, keterampilan, dan pengalaman berinteraksi dengan masyarakat majemuk dalam hal agama, suku dan budaya, perilaku, wawasan kebangsaan, etika, nilai-nilai, moral, emosi dan prinsip, yang harus dipenuhi oleh setiap pemegang Jabatan untuk memperoleh hasil kerja sesuai dengan peran, fungsi dan Jabatan. Kompetensi Sosial Kultural diukur dari pengalaman kerja berkaitan dengan masyarakat majemuk dalam hal agama, suku, dan budaya sehingga memiliki wawasan kebangsaan.

\section{E. REFERENSI}

[1] Peraturan Pemerintah Nomor 11 Tahun 2017 Tentang Manajemen PNS.
[2] Keputusan Kepala Badan Kepegawaian Negara Nomor 8 Tahun 2013 tanggal 11 Februari 2013 tentang Pedoman Perumusan Standar Kompetensi Teknis PNS. Jakarta: BAKN RI.

[3] Herkolanus. Arman, Syamsuni, dan Sugito, "Proses Pengangkatan Pegawai Negeri Sipil Dalam Jabatan struktural (Suatu Penelitian di Dinas Pendidikan Kabupaten Sintang)," Jurnal Tesis PMIS-UNTAN-IAN, 2013. [diakses di Tondano, Indonesia: 23 September 2018]

[4] Flippo. E, "Personnel Management. Singapore," McGraw-Hill, Inc, 1980.

[5] Kenezevich. S, "Administration of Public Education," New York: Harper Collins Publishers, 1984.

[6] Mitrani. A, "Manajemen Sumber Daya Manusia Berbasis Kompetensi (terjemahan)," Jakarta: PT. Intermasa, 1995.

[7] Spencer, Lyle M. \& Signe M. Spencer, “: Models for Superior Performance,"New York: John Wiley \& Sons, Inc, 1993. 